\title{
Elasmopus yucalpeten sp. n. (Crustacea, Amphipoda, Maeridae) from the northern Yucatan coast, with a key for the genus in the Gulf of Mexico and biogeographic comments
}

\author{
Carlos E. Paz-Ríos ${ }^{1}$, Pedro-Luis Ardisson ${ }^{1}$ \\ 1 Departamento de Recursos del Mar, Cinvestav. Carretera antigua a Progreso, km 6, Apdo. Postal 73 - Cordemex, 97310 Merida, Yucatan, Mexico \\ http://zoobank.org/F6172163-D67C-4804-94B2-4753B9677E6D \\ Corresponding author: Carlos E.Paz-Ríos (cpaz@mda.cinvestav.mx)
}

\begin{abstract}
Received 7 June 2014

Accepted 21 August 2014

Published 1 October 2014

Academic editor:

Matthias Glaubrecht

\section{Key Words}

A new amphipod species of the genus Elasmopus Costa, 1853 is described and illustrated based on material collected in a harbor on the northern Yucatan coast, southern Gulf of Mexico. Elasmopus yucalpeten sp. n. is recognized from its congeners by a two-articulate accessory flagellum, a group of long robust setae on the anterodistal margin of the gnathopod 2 basis, a distomedial concave portion on palm of gnathopod 2 propodus, long setae on basis posterior margin of pereopods 5-7, and an entire telson. The differences among closely related species are pointed out and they are compared with the new species. An identification key to species of the genus Elasmopus in the Gulf of Mexico and biogeographic comments at the regional and global scales are also provided.
\end{abstract}

Peracarida

Senticaudata

species diversity

taxonomy

zoogeography

Caribbean Sea

Atlantic Ocean

Pacific Ocean

Indian Ocean

\section{Introduction}

The genus Elasmopus Costa, 1853 is the most diverse genus in the family Maeridae Krapp-Schickel, 2008, roughly with 101 of the 328 species in the family distributed worldwide in temperate and tropical seas (Ahyong et al. 2011, Vader and Krapp-Schickel 2012). The species are mostly found on the continental shelf ( $\leq 200 \mathrm{~m}$ depth), mainly associated with macrophytobenthos (e.g. algae, marine angiosperm) and secondarily with epifauna (e.g. anemone-hermit crab symbiosis, sponges, zoanthids) (Souza-Filho and Senna 2009, Vader and Krapp-Schickel 2012).

Morphologically, two groups of species inside Elasmopus have been recognized by Vader and Krapp-Schickel (2012): the pectenicrus-group and the rapax-group. The first one consists of most of the species with castelloserrate posterior margins on the basis in one or more pairs of the last pereopods (pereopods 6-7); the second group consists of those species with long setae and crenulate or smooth posterior margins on the basis of the same pereopods.

Regionally, 19 nominal species of the genus Elasmopus have been reported in the western Atlantic, 11 in the tropical western Atlantic and eight in the Gulf of Mexico (Ortiz et al. 2007, LeCroy et al. 2009, Gable et al. 2010, Vader and Krapp-Schickel 2012). The reported species in the Gulf of Mexico are: Elasmopus balkomanus Thomas \& Barnard, 1988, Elasmopus lemaitrei Ortiz \& Lalana, 1994, Elasmopus levis (Smith, 1873), Elasmopus cf. magnispinatus Kunkel, 1910, Elasmopus pectenicrus (Bate, 1862), Elasmopus pocillimanus (Bate, 1862), Elasmopus 
rapax Costa, 1853 and Elasmopus thomasi Ortiz \& Lalana, 1994. Two other generic species (Elasmopus sp. A and Elasmopus sp. B) have been described regionally from the southeastern Gulf of Mexico (Florida) by LeCroy (2000), but no full description has been yet provided. Now, in the present paper, Elasmopus yucalpeten sp. n. is described from collected specimens in the northern Yucatan coast, southeastern Gulf of Mexico, thus increasing the diversity of the genus in the Gulf of Mexico to nine species. The new species belongs to the rapax-group.

\section{Material and methods}

The samples were hand collected in the Yucalpeten harbor as part of a survey in the northern Yucatan coast, southeastern Gulf of Mexico. The collected material was passed through a $0.5 \mathrm{~mm}$ sieve, fixed in $10 \%$ formalin buffered with seawater; then it was washed in freshwater, sorted and preserved in $70 \%$ ethanol. Specimens were dissected in glycerine under a dissecting microscope and illustrations were made under a compound microscope with camera lucida. The description, remarks, and morphological comparison follow the style of Appadoo and Myers (2003), Souza-Filho and Senna (2009), and Hughes and Lowry (2011). Type material is deposited in the "Colección de Invertebrados Bentónicos de Yucatán, Cinvestav (CYMX)" and in the "Colección de Referencia de Bentos Costero, El Colegio de la Frontera Sur (ECOSUR)". The following abbreviations are used in the figures: AF, accessory flagellum; EP, epimeron; G, gnathopod; H, habitus; LL, lower lip; MD, mandible; MP, maxilliped; MX, maxilla; P, pereopod; T, telson; U, uropod; UL, upper lip.

\section{Systematics}

\section{Order Amphipoda Latreille, 1816 \\ Family Maeridae Krapp-Schickel, 2008 \\ Genus Elasmopus Costa, 1853}

\section{Elasmopus yucalpeten sp. $\mathbf{n}$.}

http://zoobank.org/A76BA32A-4BC1-424E-9359-9696A281342F

Figures $1-4$

Type material. Holotype male (dissected and drawn), 6.6 $\mathrm{mm}$, Yucalpeten harbor, Yucatan, Mexico, $21^{\circ} 16.667^{\prime} \mathrm{N}$, $89^{\circ} 42.001^{\prime} \mathrm{W}, 24$ August 2010, on wood dock with algae, coll. C. E. Paz-Ríos, CYMX-1-EY. Paratypes: one female (dissected and drawn), $6.2 \mathrm{~mm}$, data as for holotype, CYMX-2-EY; four males, four females, data as for holotype, ECOSUR0164; six males, Yucalpeten harbor, Yucatan, Mexico, $21^{\circ} 16.667^{\prime} \mathrm{N}, 89^{\circ} 42.001^{\prime} \mathrm{W}, 26$ June 2012, on rock with algae, intertidal, coll. C. E. Paz-Ríos, CYMX-3-EY.

Other material. Twenty-six males, 49 females, seven unsexed, data as for holotype, CYMX-4-EY.

Type locality. Yucalpeten harbor, Yucatan, Mexico.
Diagnosis. Body dorsally setose. Antenna 1 long. Accessory flagellum two-articulated. Eyes large, ovate. Group of five long robust setae on basis anterodistal margin of gnathopod 2. Medial concave portion on palm of gnathopod 2 propodus. Long setae on basis posterior margin of pereopods 5-7. One basofacial robust seta on peduncle of uropod 1. Telson entire.

Description. Based on holotype male, $6.6 \mathrm{~mm}$ (CYMX1-EY). Body with groups of one to three setae on head, pereon and pleon. Eyes large, ovate. Lateral cephalic lobe broad, rounded, anteroventral margin with notch/slit. Antenna 1 reaching beyond half of body, longer than antenna 2 (about 2 times the antenna 2 length); peduncular article 1 subequal in length to article 2, without robust setae on posterior margin; article 2 longer than article 3 (about 1.4 times the article 3 length); flagellum with 27 articles; accessory flagellum short, two-articulated, last article minute. Antenna 2 peduncular article 2 gland cone reaching beyond end of peduncular article 3; article 4 subequal in length to article 5, flagellum with nine articles. Lower lip outer lobes with single pair of ducts, mandibular lobes apically acute. Mandible molar well developed, triturative, with plumose seta; accessory setal row with four slender blades; palp three-articulated; article 1 about as long as broad, shorter than article 2 ; article 2 slightly longer than article 3, with few long slender setae; article 3 longer than article 1, weakly falcate, long (about 3.2 times as long as broad), with comb of short robust setae along anterodistal margin and three slender apical setae. Maxilla 1 inner plate with two apical plumose setae; outer plate with seven serrate robust setae; palp two-articulated, apical part of palp article 2 with seven robust and two slender setae. Maxilla 2 inner plate with five plumose setae and a few slender seate. Maxilliped inner plate with two slender and six plumose setae on apical part; outer plate bearing ten medial/apical robust setae and six apical plumose setae.

Gnathopod 1 subchelate; coxa anterior margin slightly concave, anteroventral corner produced and rounded, ventral margin with few long setae; basis posterior margin with four long setae; merus with posterodistal tooth; carpus about 1.5 times as long as broad, subequal in length to propodus, heavily setose, with rows of long setae covering the surface and posterior margin; propodus with few rows of long marginal and superficial setae, palm acute, convex, minutely serrate, defined by two posterodistal robust setae; dactylus with one seta on anterior margin. Gnathopod 2 subchelate; coxa subrectangular, longer than broad, ventral margin with some long setae; basis stout, posterior margin with four long setae, anterodistal margin with group of five long robust setae; merus anteroventral corner produced and subquadrate; carpus posteroventral corner produced, rounded and setose; propodus expanded, anterior and posterior margin with rows and clusters respectively of long slender setae; palm about half length of propodus, acute, sculptured, with palm distal shelf subrectangular bearing group of four robust setae, distal subquadrate tooth, medial concave portion for reception of the dactylar tip, defined by 


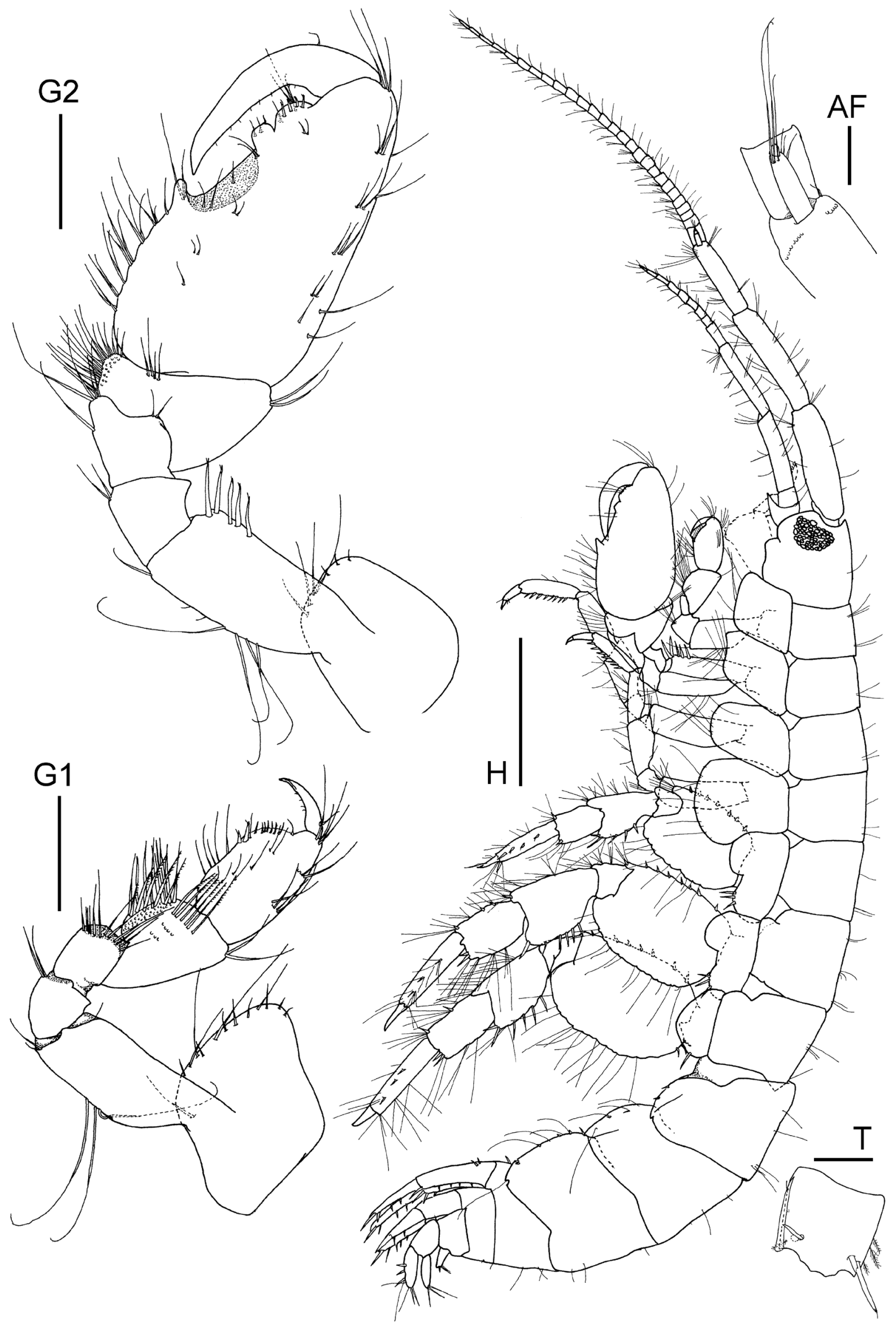

Figure 1. Elasmopus yucalpeten sp. n., holotype male, 6.6 mm, CYMX-1-EY; Yucalpeten harbor, Yucatan, Mexico. Scale bar for H represents $1 \mathrm{~mm}$; scale bars for G1 and G2 represent $0.3 \mathrm{~mm}$; scale bars for AF and T represent $0.1 \mathrm{~mm}$. 


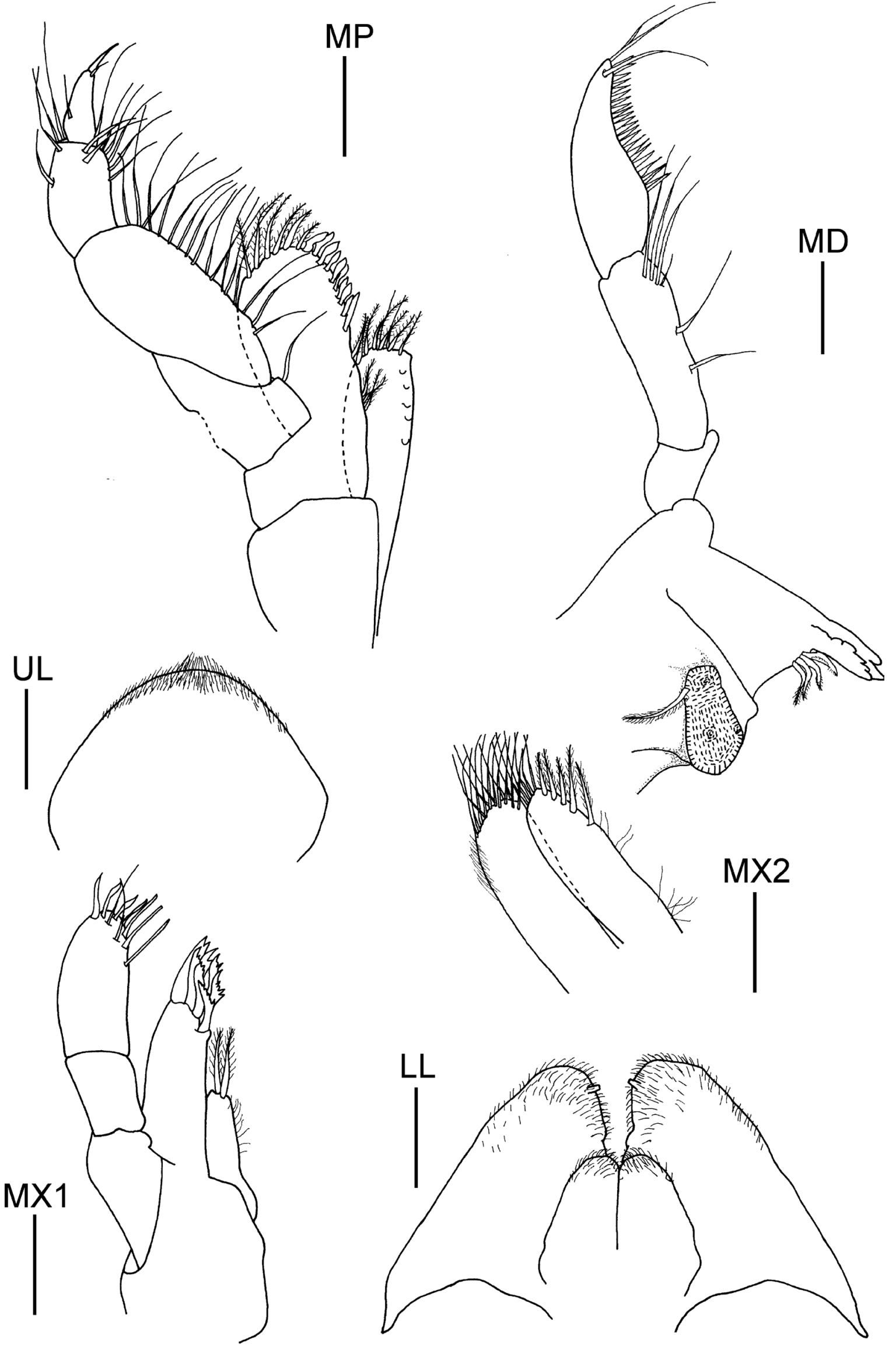

Figure 2. Elasmopus yucalpeten sp. n., holotype male, $6.6 \mathrm{~mm}$, CYMX-1-EY; Yucalpeten harbor, Yucatan, Mexico. Scale bars represent $0.1 \mathrm{~mm}$. 
proximal tooth; dactylus falcate, with one seta on anterior margin. Pereopod 3 similar to pereopod 4, except by the coxa subrectangular. Pereopod 4 coxa longer than broad, posterior margin concave, posteroventral corner produced and rounded, ventral margin with long setae; basis posterior margin with three long setae; propodus with a row of seven robust setae on posterior margin; dactylus short (about 0.5 times the propodus length), dactylar unguis simple. Pereopod 5-6 coxa broader than long, excavate ventrally, anteroventral lobe produced and rounded, with three posteroventral robust setae; basis posterior margin slightly expanded convex, weakly crenulate, with many long stiff slender setae; ischium, merus, carpus and propodus with many long, slender and robust setae along margins; dactylus short (about 0.3 times the propodus length), dactylar unguis simple. Pereopod 7 similar to pereopod 5-6, except by the coxa with ventral lobe produced and rounded, with one posterior robust seta.

Epimera 1-3 posteroventral corner notched with small subacute tooth; ventral margin with long slender and robust setae. Urosomite 1-3 smooth, without carina. Uropod 1 peduncle with two basofacial robust setae, five robust setae on each of the outer and inner margins, and two long robust setae distally; inner ramus about as long as peduncle. Uropod 2 peduncle with two and three robust setae on outer and inner margin, respectively; inner ramus longer than peduncle (about 1.2 times the peduncle length). Uropod 3 peduncle with two distal robust setae; inner ramus about as long as peduncle; outer ramus slightly longer than inner ramus with three clusters of long setae. Telson entire with posterior margin scalloped, two unequal stout robust setae and two or three plumose setae on each side.

Female (sexually dimorphic characters); based on paratype female, $6.2 \mathrm{~mm}$ (CYMX-2-EY). Gnathopod 1 subchelate; coxa ventral margin with short setae; basis medial surface with two long setae, posterior margin with seven long setae; carpus heavily setose, with long setae covering the surface and posterior margin; propodus with marginal and superficial setae, palm acute, convex, minutely serrate, with ten submarginal robust setae, defined by two posterodistal robust setae, followed by two submarginal robust setae; dactylus not reaching the end of palm, with one seta on anterior margin. Gnathopod 2 subchelate; coxa ventral margin with some long setae; basis posterior margin with five long setae, anterodistal margin with one long robust setae; carpus heavily setose, with long setae covering the posterior margin; propodus anterior and posterior margin with rows and clusters respectively of long slender setae, about twice length of carpus, palm acute, nearly straight, smooth, with 15 submarginal robust setae, defined by three posterodistal robust setae; dactylus falcate, not reaching the end of palm, with one seta on anterior margin. Pereopod 5-7 with few long stiff slender setae. Uropod 1 peduncle with one basofacial robust seta.

Variations; based on paratypes (CYMX-2-EY, CYMX3-EY, ECOSUR0164). A group of six robust setae (instead of five) on the anterodistal margin of the basis of gnathopod 2 was observed in two of the ten male spec- imens. Male and female specimens were also examined for confirming the presence of two robust setae on peduncle of uropod 1, but there was not consistency; the rule was to present one basofacial robust seta.

Etymology. The species name is derived from the type locality of the new species. Yucalpeten in the Mayan language means "land of the deer".

Distribution. So far only known from the type locality, Yucalpeten harbor, Yucatan, Mexico.

Habitat. Marine epibenthic, in shallow water $(\leq 1 \mathrm{~m})$ on rocks and wood dock with the brown algae Gracilaria sp.

Remarks. The presence of one or two basofacial robust setae on uropod 1 peduncle as a characteristic for species category identification may have been overlooked by earlier studies (Hughes and Lowry 2011); these same authors also have pointed out that, the presence of two basofacial robust setae on uropod 1 peduncle may be result of a newly-forming moult stage, such as the present case, where only the holotype male bears those spines. Elasmopus yucalpeten sp. $\mathrm{n}$. is distinguished from the rest of the species in the genus by having the antenna 1 accessory flagellum two-articulated, mandibular palp article 3 weakly falcate, gnathopod 2 basis anterodistal margin with group of long robust setae, gnathopod 2 propodus palm with medial concave portion, uropod 1 peduncle with one or rarely two basofacial robust setae, and telson entire. An entire telson is only known in four other species of the genus, Elasmopus integer Myers, 1989, Elasmopus pseudinteger Appadoo \& Myers, 2003, Elasmopus takamotus Myers, 1986, and Elasmopus visakhapatnamensis Kanakadurga, Rao \& Shyamasundari, 1981. Of these species, E. yucalpeten sp. n. is closely related to E. integer from Bora Bora, South Pacific, E. pseudinteger from Mauritius, Indian Ocean, and E. visakhapatnamensis from Visakhapatnam, Indian Ocean. It is distinguished from $E$. integer by the eyes ovate; mandibular palp article 3 weakly falcate; gnathopod 2 propodus palm with medial concave portion; pereopod 5-7 basis more setose; and epimera 2-3 posteroventral corner notched with small subacute tooth. It is distinguished from E. pseudinteger by the two-articulated accessory flagellum; the more setose mandibular palp article 2; the long slender setae along the anterior and posterior margin of the gnathopod 2 propodus; the entire, crenulate and more setose margin of the pereopod 5-6 basis; the margin evenly convex of the epimeron 3 with the posteroventral corner notched and a small subacute tooth; the presence of one basofacial robust setae on the uropod 1 peduncle; and a telson with a scalloped posterior margin. Finally, it is distinguished from $E$. visakhapatnamensis by the following characteristics: mandibular palp article 3 weakly falcate; gnathopod 2 propodus palm with medial concave portion and proximal tooth; epimeron 1-3 margin evenly convex with posteroventral corner notched, having a small subacute tooth; and uropod 3 outer ramus longer than inner ramus. 


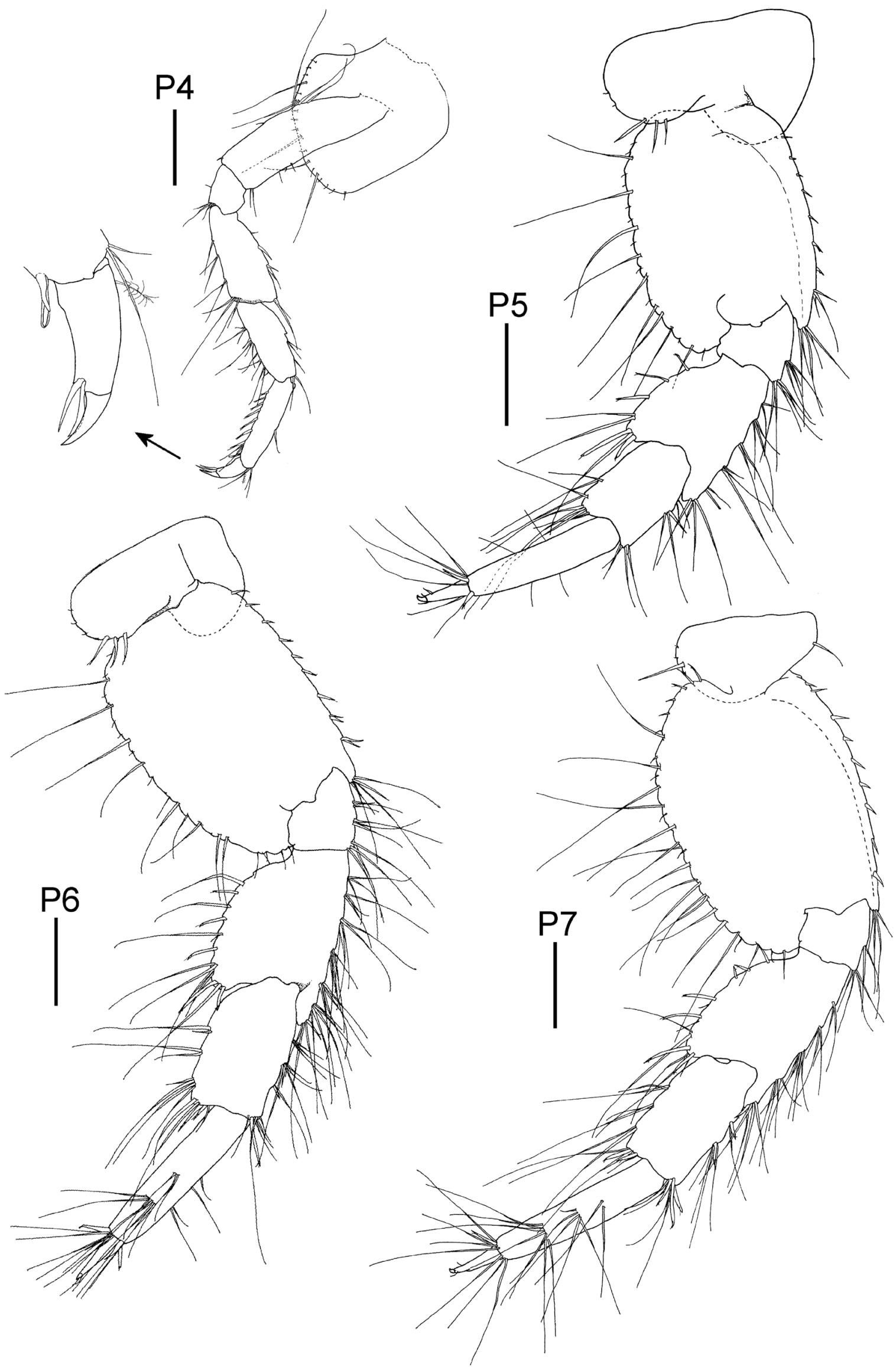

Figure 3. Elasmopus yucalpeten sp. n., holotype male, $6.6 \mathrm{~mm}$, CYMX-1-EY; Yucalpeten harbor, Yucatan, Mexico. Scale bars represent $0.3 \mathrm{~mm}$. 

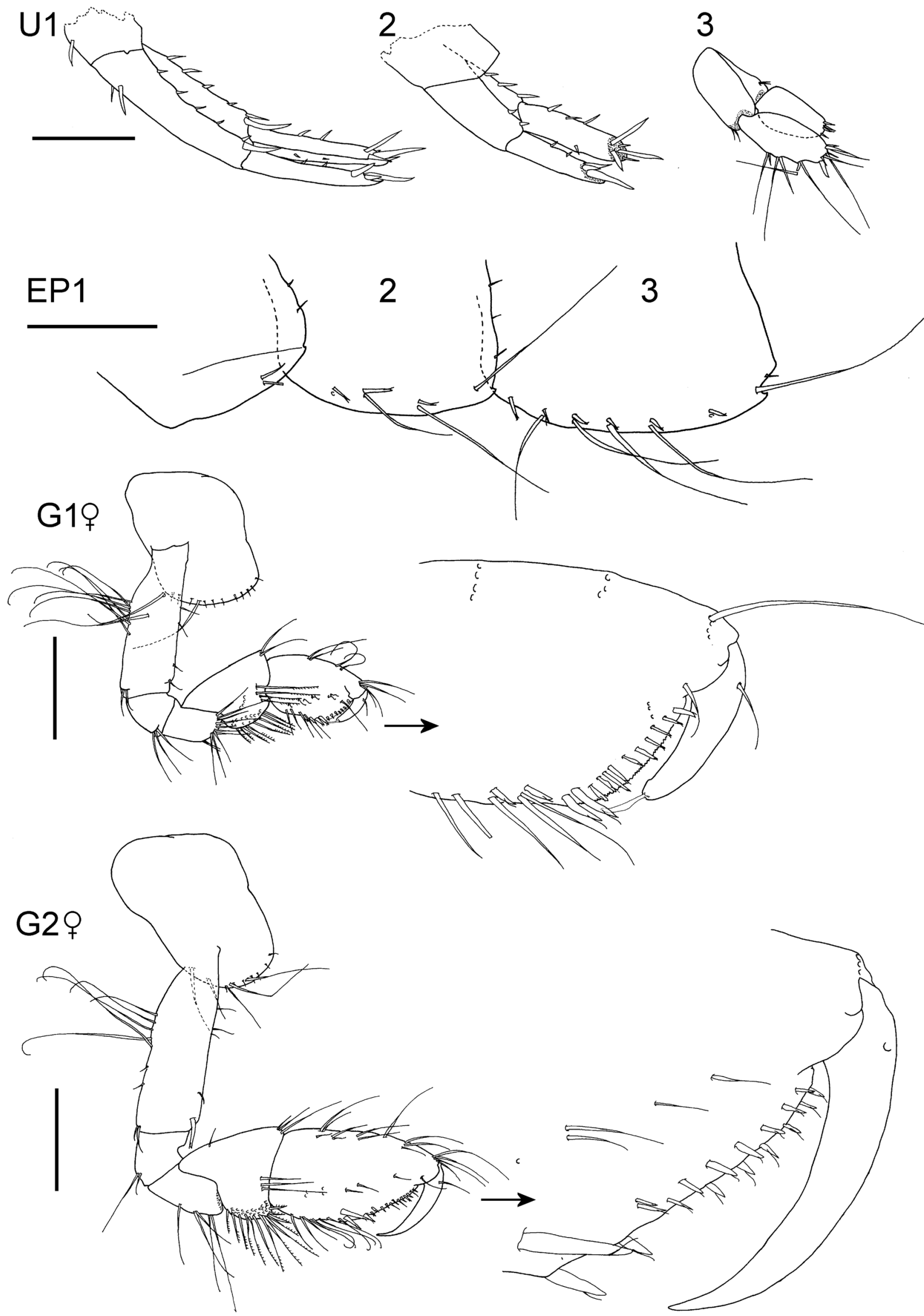

Figure 4. Elasmopus yucalpeten sp. n., holotype male, $6.6 \mathrm{~mm}$, CYMX-1-EY; paratype female, $6.2 \mathrm{~mm}$, CYMX-2-EY; Yucalpeten harbor, Yucatan, Mexico. Scale bars represent $0.3 \mathrm{~mm}$. 


\section{Key to Elasmopus species in the Gulf of Mexico (modified from Vader and Krapp-Schickel 2012)}

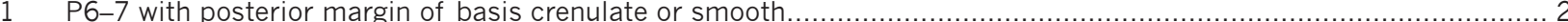
P6 (not P7) with posterior margin of basis partly castelloserrate ................................................... E. pectenicrus

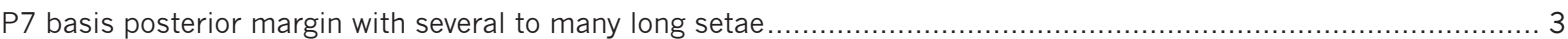

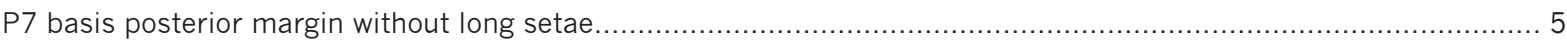

G2 basis anterodistal margin with group of robust setae. Telson entire ............................................ yucalpeten sp. n.

G2 basis anterodistal margin without group of robust setae. Telson cleft.................................................. 4

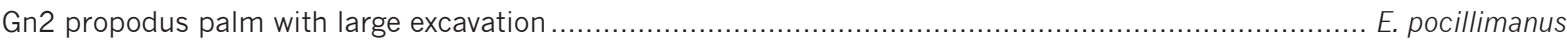

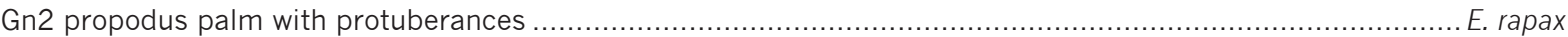

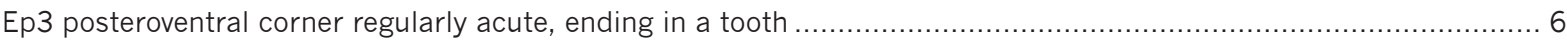

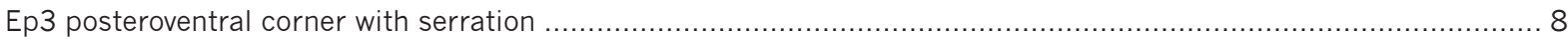

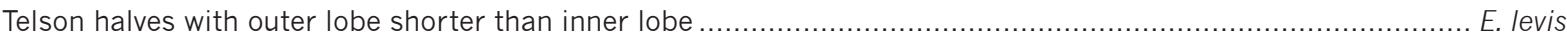

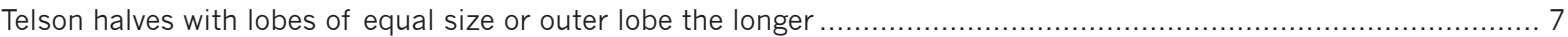

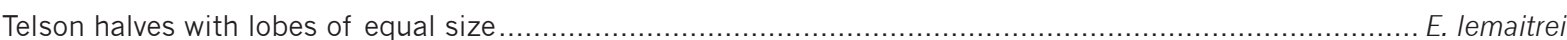

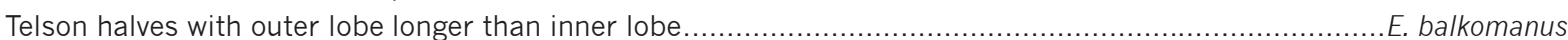

$\mathrm{Gn} 2$ basis anterodistal margin produced. U3 with rami subequal .......................................... E. cf. magnispinatus

Gn2 basis anterodistal margin not produced. U3 with rami clearly unequal ............................................ E. thomasi

\section{Biogeographic comments}

Up to now, nine species of Elasmopus (including the new species) have been recorded in the Gulf of Mexico (Table 1). At the horizontal axis, according to the regionalization of Felder et al. (2009) for the Gulf of Mexico basin, three of those species (E. levis, E. pocillimanus and E. rapax) have been widely reported in the Gulf basin regions, two species (E. balkomanus and E. pectenicrus) have been mostly reported in the northern regions, and the remaining four species are so far confined (endemic) to the northeast region (E. cf. magnispinatus) or southeast region (E. lemaitrei, E. thomasi and E. yucalpeten sp. n.). At the vertical axis, according to the zonation by depth of Yáñez-Arancibia and Day (2004) for the Gulf of Mexico basin, all species have been reported on the coastal shallow $(0-20 \mathrm{~m})$ and only four species have been reported on the continental shelf (21-200 m). Furthermore, those species more widely distributed in the Gulf of Mexico also displayed a broad range of depth; in contrast, species with a constricted distribution displayed a narrow range of depth. Nevertheless, as LeCroy (2000) has pointed out for Elasmopus species narrowly distributed, further samplings may reveal that those species are actually more widespread than previously expected, for example, E. cf. magnispinatus has been reported only from the northeast region, but with a great number of records and a broad range of depth.

Regionally, the amphipod fauna in the Gulf of Mexico shows an affinity to the biogeographic provinces from the tropical western Atlantic (Carolinian and Caribbean) quoted by Neigel (2009) and Briggs and Bowen (2012). The Carolinian province corresponds to northern regions (NW and NE) representing a warm-temperate condition; whereas the Caribbean province corresponds to southern regions (SW and SE) representing a tropical condition. According to those provinces, the genus Elasmopus has species with tropical and temperate affinities. The tropical component is dominant with eight species, three of which are endemic so far for the Gulf of Mexico (Table 1). Globally, E. yu-
Table 1. Distribution data and biogeographic affinity of the Elasmopus species in regions of the Gulf of Mexico. Regions after Felder et al. (2009): SW, Southwest; NW, Northwest; NE, Northeast; SE, Southeast. Information based on Ortiz and Lalana (1994), LeCroy (2000), LeCroy et al. (2009), Vader and Krapp-Schickel (2012), and Paz-Ríos et al. (2013).

\begin{tabular}{l|c|c|c|c|c|c|c}
\hline Species & SW & NW & NE & SE & $\begin{array}{c}\text { Depth } \\
(\mathbf{m})\end{array}$ & Carolinian & Caribbean \\
\hline E. balkomanus & & & $\bullet$ & $\bullet$ & $1-3$ & $\bullet$ & $\bullet$ \\
\hline E. lemaitrei & & & & $\bullet$ & $<1-3$ & & $\bullet$ \\
\hline E. levis & $\bullet$ & $\bullet$ & $\bullet$ & $\bullet$ & $0-18$ & $\bullet$ & $\bullet$ \\
\hline E. pectenicrus & & $\bullet$ & $\bullet$ & $\bullet$ & $0-50$ & $\bullet$ & $\bullet$ \\
\hline E. pocillimanus & $\bullet$ & $\bullet$ & $\bullet$ & $\bullet$ & $0-30$ & $\bullet$ & $\bullet$ \\
\hline E. rapax & $\bullet$ & $\bullet$ & $\bullet$ & $\bullet$ & $1-50$ & $\bullet$ & $\bullet$ \\
\hline E. thomasi & & & & $\bullet$ & $<1-3$ & & $\bullet$ \\
\hline E. cf. magnispinatus & & & $\bullet$ & & $6-55$ & $\bullet$ & \\
\hline E. yucalpeten sp.n. & & & & $\bullet$ & $\leq 1$ & & $\bullet$ \\
\hline
\end{tabular}

calpeten sp. n. is geographically related to four species which in turn are morphologically similar by a unique trait in the genus, an entire telson. Moreover, from those species, E. yucalpeten sp. n. is similar to three species of the rapax-group (E. integer, E. pseudinteger and E. visakhapatnamensis) by an anterodistal margin of gnathopod 2 basis with group of long robust setae and P5-7 basis having long setae, revealing possibly a separate complex of widely distributed species. The distribution of those species resembles the trans-Indo-Pacific-Caribbean tracks described by Myers and Lowry (2009) (Figure 5), which is explained by plate tectonic/sea-level changes during the Cretaceous and is represented by distribution of a number of amphipod taxa at the family category (e.g. Neomegamphopidae) and genus (e.g. Mallacoota, Shoemakerella). Therefore, with the similarity among species closely related to Elasmopus it was possible to recognize that biogeographic track, which proposes according to Myers (1991) and Myers and Lowry (2009) an ancient connection among seas and a current isolation by means of disjunct distributions of related taxa. 


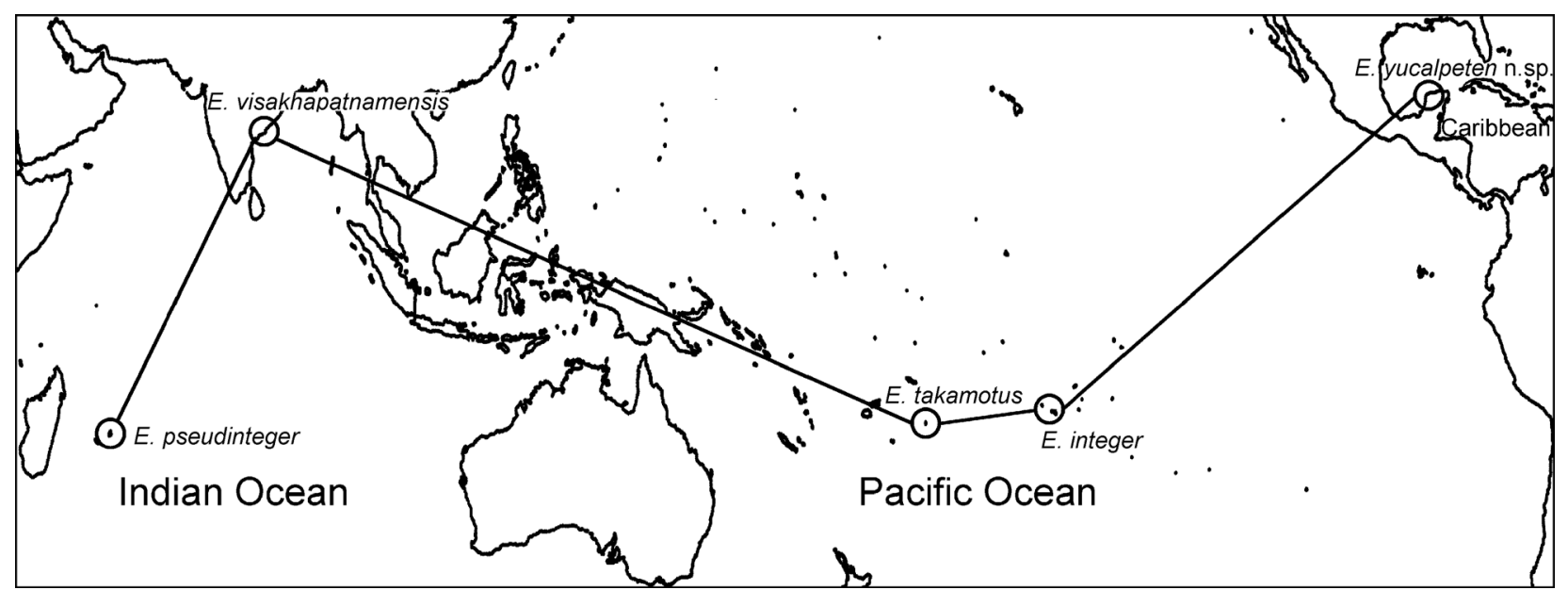

Figure 5. Distribution of species closely related to E. yucalpeten sp. n.

\section{Acknowledgments}

We thank Maria Teresa Herrera-Dorantes (Laboratorio de Bentos, Cinvestav) for her support during the field sampling, as well as to Luis F. Carrera Parra and Norma E. González Vallejo (ECOSUR, Chetumal) for the deposition of a part of the type material in the reference collection of ECOSUR. Special thanks are also due to Rachael A. Peart (Australian Museum, Sydney) for reading the manuscript and for her valuable comments/suggestions. The authors thank two reviewers who kindly helped to improve the manuscript.

\section{References}

Ahyong ST, Lowry J, Alonso M, Bamber RN, Boxshall GA, Castro P, Gerken S, Karaman GS, Goy JW, Jones DS, Melanda K, Rogers DC, Svavarsson J (2011) Subphylum Crustacea Brünnich, 1772. In: Zhang Z-Q (Ed.) Animal biodiversity: An outline of higher-level classification and survey of taxonomic richness. Zootaxa 3148 : $165-191$.

Appadoo C, Myers AA (2003) The genus Elasmopus (Crustacea: Amphipoda: Melitidae) from Mauritus (Indian Ocean) with description of five new species. Records of the Australian Museum 55: 61-84. doi: 10.3853/j.0067-1975.55.2003.1375

Bate CS (1862) Catalogue of the specimens of amphipodous Crustacea in the collections of the British Museum, London. British Museum of Natural History 4: 1-399.

Briggs JC, Bowen BW (2012) A realignment of marine biogeographic provinces with particular reference to fish distributions. Journal of Biogeography 39(1): 12-30. doi: 10.1111/j.1365-2699.2011.02613.x

Costa A (1853) Relazione sulla memoria del Dottor Achille Costa, di ricerche su' crostacei amfipodi del regno di Napoli. Rendiconto della Societa Reale Borbonica, Accademia delle Scienze, new series 2: 167-178.

Felder DL, Camp DK, Tunnell Jr. JW (2009) An Introduction to Gulf of Mexico Biodiversity Assessment. In: Felder DL, Camp DK (Eds) Gulf of Mexico: Origins, Waters and Biota, Volume 1: Biodiversity. Texas A\&M University Press, Corpus Christi, 1-12.
Gable MF, Lazo-Wasem EA, Baldinger AJ (2010) The Amphipoda of Bermuda-A century of taxonomy. Zoologica Beatica 21: 131-141.

Hughes LE, Lowry JK (2011) The genus Elasmopus (Crustacea: Amphipoda: Maeridae) in Australian waters. Journal of Natural History 45(9-10): 579-628. doi: 10.1080/00222933.2010.534825

Kanakadurga MR, Rao KH, Shyamasundari K (1981) Two new species of amphipods (Crustacea) from Waltair coast sponge Callyspongia fibrosa. The Indian Journal of Zootomy 22(2): 71-80.

Krapp-Schickel T (2008) What has happened with the Maera-clade during the last decades? Bollettino del Museo Civico di Storia Naturale di Verona, Botanica Zoologia 32: 3-32.

Kunkel BW (1910) The Amphipoda of Bermuda. Transactions of the Connecticut Academy of Arts and Science 16: 1-116.

Latreille PA (1816) Amphipoda. Nouveau Dictionaire d'histoire naturelle, appliquée aux Arts, à l'Agriculture, à l'Économie rurale et domestique, à la Médecine, etc. Par une société de Naturalistes et d'Agriculteurs, $2^{\text {nd }}$ edition, Volume 1. Deterville, Paris, 467-469.

LeCroy SE (2000) An Illustrated Identification Guide to the Nearshore Marine and Estuarine Gammaridean Amphipoda of Florida, Volume 1: Families Gammaridae, Hadziidae, Isaeidae, Melitidae and Oedicerotidae. Florida Department of Environmental Protection, Tallahassee, $195 \mathrm{pp}$.

LeCroy SE, Gasca R, Winfield I, Ortiz M, Escobar-Briones E (2009) Amphipoda (Crustacea) of the Gulf of Mexico. In: Felder DL, Camp DK (Eds) Gulf of Mexico: Origins, Waters and Biota, Volume 1: Biodiversity. Texas A\&M University Press, Corpus Christi, 941-972.

Myers AA (1986) Amphipoda from the South Pacific: Niue Island. Journal of Natural History 20(6): 1381-1392. doi: 10.1080/00222938600770921

Myers AA (1989) Amphipoda from the South Pacific: the Society Island. Records of the Australian Museum 41: 63-82. doi: 10.3853/ j.0067-1975.41.1989.136

Myers AA (1991) How did Hawaii accumulate its biota? A test from the Amphipoda. Global Ecology and Biogeography Letters 1(1): 24-29. http://www.jstor.org/stable/2997541

Myers AA, Lowry JK (2009) The biogeography of Indo-West Pacific tropical amphipods with particular reference to Australia. In Lowry JK, Myers AA (eds). Benthic Amphipoda (Crustacea: Peracarida) of the Great Barrier Reef, Australia. Zootaxa 2260: 109-127. 
Neigel JE (2009) Population genetic and biogeography of the Gulf of Mexico. In: Felder DL, Camp DK (Eds) Gulf of Mexico: Origins, Waters and Biota, Volume 1: Biodiversity. Texas A\&M University Press, Corpus Christi: 1353-1369.

Ortiz M, Lalana R (1994) Two new species of the genus Elasmopus (Amphipoda: Gammaridea), from the Cuban marine waters. Travaux du Muséum National d'Histoire naturelle "Grigore Antipa" 34: 293302. http://www.travaux.ro/web/pdf/34-TMNHNGA-293-302.pdf

Ortiz M, Martín A, Díaz YJ (2007) Lista y referencias de los crustáceos anfípodos (Amphipoda: Gammaridea) del Atlántico occidental tropical. Revista de Biología Tropical 55(2): 479-528. doi: 10.15517/ rbt.v55i2.6026, http://www.scielo.sa.cr/pdf/rbt/v55n2/3646.pdf

Paz-Ríos CE, Simões N, Ardisson P-L (2013) Intertidal and shallow water amphipods (Amphipoda: Gammaridea and Corophiidea) from Isla Pérez, Alacranes Reef, southern Gulf of Mexico. Nauplius 21(2): 179-194. doi: 10.1590/S0104-64972013000200005

Smith SI (1873) Crustacea, ex Isopoda. In: Verrill AE (Ed.) Report upon the invertebrate animals of Vineyard Sound, Part 1: Report on the Condition of the Sea Fisheries of the South Coast of New England in 1871 and 1872. U.S. Commission of Fish and Fisheries, Washington: 295-778.

Souza-Filho JF, Senna AR (2009) Two new species of the genus Elasmopus Costa, 1853 (Amphipoda: Gammaridea: Maeridae) from off the northeast Brazilian coast. Zootaxa 2301: 55-68. http://www.mapress.com/zootaxa/2009/f/z02301p068f.pdf

Thomas JD, Barnard JL (1988) Elasmopus balkomanus, a new species from the Florida Keys (Crustacea: Amphipoda). Proceedings of the Biological Society of Washington 101(4): 838-842. http://biostor. org/reference $/ 74758$

Vader W, Krapp-Schickel T (2012) On some maerid and melitid material (Crustacea: Amphipoda) collected by the Hourglass Cruises (Florida). Part 2: Genera Dulichiella and Elasmopus, with a key to world Elasmopus. Journal of Natural History 46(19-20): 1179-1218. doi: 10.1080/00222933.2011.652984

Yáñez-Arancibia A, Day JW (2004) The Gulf of Mexico: towards an integration of coastal management with large marine ecosystem management. Ocean \& Coastal Management 47(11-12): 537-563. doi: 10.1016/j.ocecoaman.2004.12.001 